\title{
Penerapan Metode Simulasi Dalam Meningkatkan Kemampuan Teknik Dasar Permainan Bola Besar Pada Siswa SMP Negeri 4 Siak Hulu
}

\author{
SALMI \\ Dinas Pendidikan Kabupaten Kampar \\ SMP Negeri 4 Siak Hulu \\ E-mail : salmi_smp4@gmail.com
}

\begin{abstract}
The lesson of playing big ball is a fun lesson for students, because this lesson is accompanied by the practice of the game. But in the practice of playing sometimes students don't get enough theory from the teacher. In addition to playing in the simulation field through educative game tools will provide a solution to overcome this problem. Through classroom action research by applying to students in the 4 Siak Hulu Public Middle School with qualitative analysis techniques obtained results that are proven by the application of simulation methods to be able to improve the mastery skills of the big ball playing techniques.
\end{abstract}

Keywords: Simulation Methods and Basic Engineering Capabilities, Big Ball Games

Pendidikan jasmani adalah suatu proses pendidikan seseorang sebagai perorangan atau anggota masyarakat yang dilakukan secara sadar dan sistematik melalui berbagai kegiatan jasmani untuk memperoleh pertumbuhan jasmani, kesehatan dan kesegaran jasmani, kemampuan dan keterampilan, kecerdasan dan perkembangan watak serta kepribadian yang harmonis dalam rangka pembentukan manusia Indonesia berkualitas berdasarkan Pancasila.

Secara sederhana, pendidikan jasmani memberikan kesempatan kepada murid untuk: Mengembangkan pengetahuan dan keterampilan yang berkaitan dengan aktivitas jasmani, perkembangan estetika, dan perkembangan social; Mengembangkan kepercayaan diri dan kemampuan untuk menguasai keterampilan gerak dasar yang akan mendorong partisipasinya dalam aneka aktivitas jasmani; Memperoleh dan mempertahankan derajat kebugaran jasmani yang optimal untuk melaksanakan tugas sehari-hari secara efisien dan terkendali; Mengembangkan nilai-nilai pribadi melalui partisipasi dalam aktivitas jasmani baik secara kelompok maupun perorangan; Berpartisipasi dalam aktivitas jasmani yang dapat mengembangkan keterampilan sosial yang memungkinkan murid berfungsi secara efektif dalam hubungan antar orang dan menikmati kesenangan dan keriangan melalui aktivitas jasmani, termasuk permainan olahraga.

Permaian bola besar bermacammacam seperti sepak bola, bola volly, basket, takraw dan lainnya merupakan bentuk permainan yang unik dan mulai dipermainkan dari kalangan anak-anak, remaja dan bahkan orang dewasa/tua.semua menyukai permaian ini.Permainan ini membutuhkan rasa percaya diri yang besar, karena dilihat banyak orang. Percaya diri merupakan suatu keyakinan dan sikap seseorang terhadap kemampuan pada dirinya sendiri dengan menerima secara apa adanya baik positif maupun negatif yang dibentuk dan dipelajari melalui proses belajar dengan tujuan untuk kebahagiaan dirinya. Seseorang yang percaya diri dapat menyelesaikan tugas atau pekerjaan yang sesuai dengan tahapan perkembangan dengan baik, merasa berharga, mempunyai keberanian, dan kemampuan untuk meningkatkan prestasinya, mempertimbangkan berbagai pilihan, serta membuat keputusan sendiri 
merupakan perilaku yang mencerminkan percaya diri (Lie, 2003)

Topik pembelajaran praktek gerak dasar permainan bola besar sederhana dengan peraturan yang dimodifikasi bertujuan agar murid dapat melakukan dan memahami permainan sepak bola. Teknik dasar dalam permainan sepak bola terdiri dari menendang, menerima/mengontrol, menggiring, dan menyundul bola. Pada bab ini, kalian akan mempelajari beberapa dari teknik tersebut.

Namun berdasarkan data ketuntasan belajar murid mengenai praktek bola besar ini masih belum tuntas, dan ternyata banyak penyebabnya, antara lain karena murid kurang memahami teori dan kurang percaya dalam mempraktekkannya di lapangan. Selain itu juga karena metode pembelajaran yang diberikan guru kepada murid nya kurang sesuai dan tidak membuat murid semakin aktif bertanya dan juga mempraktekkan perminan bola besar.

Salah satu contoh adalah bola voli.Bola voli adalah olahraga permainan yang dimainkan oleh dua grup berlawanan.Masing-masing grup memiliki enam orang pemain.Terdapat pula variasi permainan bola voli pantai yang masingmasing grup hanya memiliki dua orang pemain. Untuk dapat memainkan permainan bola voli tidak dapat dilaksanakan denga asal-asalan begitu saja, namun harus mentaati beberapa peraturan yang telah di tetapkan seperti posisi, cara bermainan, Lapangan, dan masih banyak lagi.

Pelaksanaan proses pembelajaran sama dengan pelaksanaan proses belajar menagajar. B.Suryosubroto (2002: 36) mengemukakakn bahwa pelaksanaan proses belajar mengajar adalah proses berlangsungnya belajar mengajar di kelas yang merupakan inti dari kegiatan pendidikan di sekolah. Winarno Surachmad (1983: 257) menambahkan bahwa pelaksanaan pengajaran adalah interaksi guru dengan murid dalam rangka penyampaian bahwa pelajaran keapda murid dan untuk mencapai tujuan pengajaran. Berdasarkan kajian pustaka dapat disimpulkan bahwa pelaksanaan pembelajaran adalah sebagai terjadinya interaksi guru dengan murid dalam rangka menyampaikan bahan pelajaran kepada murid untuk mencapai tujuan.

Proses pembejalaran yang dilaksanakan oleh guru diutamakan mengacu pada kemampuan yang akan dicapai dan mengoptimalkan pemberian pengajaran yang kreatif pada anak didik dengan menggunakan Alat Permainan Edukatif (APE). Moh. Uzer Usman (2001: 4) menyatakan bahwa pembelajaran merupakan suatu proses yang mengandung serangkaian perbuatan guru dan murid atas dasar hubungan timbal balik yang berlangsung dalam situasi edukatif untuk mencapai tujuan tertentu. Interaksi atau hubungan timbal balik antara guru dan murid itu merupakan syarat utama bagi berlangsungnya proses belajar mengajar. Dalam hal ini bukan hanya menyampaikan pesan berupa materi pembelajaran melainkan penanaman sikap dan nilai pada diri murid yang sedang belajar.

Alat sama dengan media kata media berasal dari bahasa Latin medius yang secara harfiah berarti 'tengah', 'perantara' atau 'pengantar'. Dalam bahasa Arab, media adalah perantara attau pengantar pesan dari pengirim kepada penerima pesan. Gerlach \& Ely (1971) (dalam Arsyad: 2005: 7) menyatakan bahwa media apabila dipahami secara garis besar adalah manusia, mnateri, atau kejadian yang membangun kondisi yang membuat murid mampu memperoleh pengetahuan, keterampilan, atau sikap. Dalam pengertian ini, guru, buku teks, dan lingkungan sekolah merupakan media. bicara lebih khusus. pengertian media dalam proses belajar mengajar cenderung diartikan sebagai alat-alat grafis, photografis, atau elektronis untuk menangkap, memproses, dan menyusun kembali informasi visual atau verbal. 


\section{METODE}

Metode yang digunakan dalam penelitian ini adalah metode penelitian tindakan kelas merupakan: (1) penelitian partisipatoris yang menekankan pada tindakan dan refleksi berdasarkan pertimbangan rasional dan logis untuk melakukan perbaikan terhadap suatu kondisi nyata; (2) memperdalam pemahaman terhadap tindakan yang dilakukan dan (3) memperbaiki situasi dan kondisi kelas pembelajaran secara praktis". Yang menjadi subjek penelitian tindakan kelas ini adalah guru bersama dengan murid kelas IX SMP N 4 Siak Hulu.

Tindakan yang dilakukan dalam penelitian ini adalah menerapakan alat edukatif simulasin komputer kepada murid dalam rangka meningkatkan hasil belajar permainan bola besar kelas IX mata pelajaran Pendidikan jasmani dan olahraga SMP N 4 Siak Hulu. Karena keterbatasan waktu, penelitian tindakan kelas ini hanya dilaksanakan sebanyak 3 siklus masingmasing siklus dilaksanakan selama 3 minggu.

Teknik pengumpulan data dari penelitian tindakan kelas ini adalah melalui data kualitatif yang diperoleh dari observasi, pengamatan, maupun wawancara. Analisa data yang digunakan dalam penelitian ini adalah analisa data kualitatif yang bersumber dari data primer maupun empiris. Melalui analisa data ini, dapat diketahui baik atau tidaknya hasil belajar murid pada mata pelajaran pendidikan jasmani dan olahraga melalui penerapan alat edukasi simulasi komputer yang merupakan fokus dari penelitian tindakan kelas ini.

\section{HASIL}

Penelitian tindakan kelas (PTK) ini dilaksanakan dalam dua siklus. Hal ini dikarenakan keterbatasan waktu yang tersedia, serta dengan dua siklus sudah penulis anggap cukup untuk peningkatan hasil belajar permainan bola besar murid pada mata pelajaran pendidikan jasmani dan olahraga di kelas.

\section{Siklus 1}

Siklus 1 terdiri beberapa tahapan, yaitu: 1) Perencanaan; 2) Pelaksanaan; 3) Pengamatan dan 4) Refleksi. Rekapitulasi hasil belajar murid pada mata pelajaran pendidikan jasmani dan olahraga melalui penerapan alat edukatif simulasi komputer dalam meningkatkan hasil belajar di kelas IX mata pelajaran pendidikan jasmani dan olahraga dapat dilihat pada tabel rekap diketahui pada siklus pertama hasil belajar murid pada mata pelajaran pendidikan jasmani dan olahraga melalui penerapan alat edukatif simulasi komputer di kelas IX dinyatakan tuntas sebanyak $50 \%$. Hal ini dikarenakan banyak murid yang masih kurang mengerti penggunaan alat edukasi simulasi komputer tersebut pada saat dijelaskan oleh guru didepan.

\section{Siklus 2}

Siklus 2 terdiri beberapa tahapan yang sama seperti siklus 1, yaitu: 1) Perencanaan; 2) Pelaksanaan; 3) Pengamatan dan 4) Refleksi. Rekapitulasi hasil belajar murid pada mata pelajaran pendidikan jasmani dan olahraga dengan penerapan alat edukatif simulasi komputer melalui materi permainan bola besar di kelas IX dapat dilihat pada tabel rekap diketahui pada siklus kedua hasil pekerjaan rumah murid mata pelajaran pendidikan jasmani dan olahraga dinyatakan baik, dengan ketuntasan yang mencapai $65.6 \%$ bahwa adanya perubahan dari siklus kedua dan perlu dilanjutkan ke siklus ke 3 .

\section{Siklus 3}

Siklus 3 terdiri beberapa tahapan yang sama seperti siklus 1, yaitu: 1) Perencanaan; 2) Pelaksanaan; 3) Pengamatan dan 4) Refleksi. Dari hasil rekapitulasi data tersebut dapat diketahui pada siklus kedua hasil pekerjaan rumah murid mata pelajaran pendidikan jasmani dan olahraga dinyatakan baik, dengan ketuntasan yang mencapai $100 \%$ dan dapat disimpulkan bahwa adanya perubahan dari 
siklus kedua.

\section{PEMBAHASAN}

Setelah selesai pelaksanaan tindakan pada siklus kedua maka diadakan refleksi mengenai kelemahan atau kekurangan dari pelaksanaan tindakan pada siklus kedua tersebut. Refleksi dilaksanakan bersamasama berkolaborator untuk menentukan tindakan perbaikan pada siklus berikutnya. Dari hasil observasi dan data yang diperoleh, peneliti mengambil kesimpulan bahwa tindakan yang dilaksanakan pada siklus kedua dinyatakan lebih baik bila dibandingkan dengan siklus pertama dan penulis nyatakan cukup sampai di siklus 3 dikarenakan keterbatasan waktu dan sudah ada peningkatan yang signifikan dari pada siklus 1 .

Untuk lebih jelasnya dapat dilihat pada grafik berikut ini:

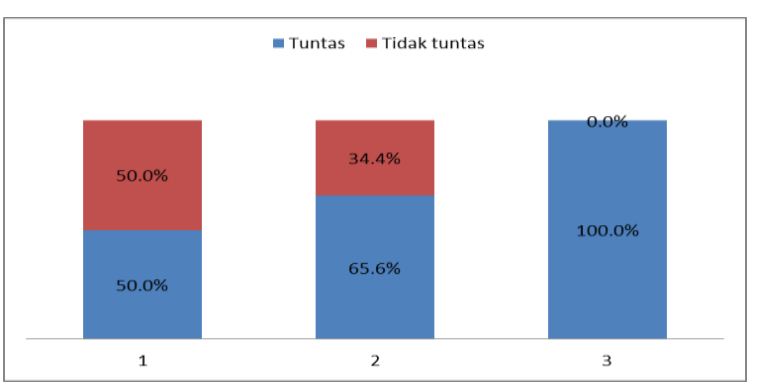

Berdasarkan analisis data, dari penelitian ini dapat diketahui bahwa, penerapan alat belajar edukatif simulasi komputer dalam rangka meningkatkan hasil belajar permainan bola besar murid di kelas IX pada mata pelajaran pendidikan jasmani dan olahraga ternyata hasil belajar murid meningkat. Dari awalnya hanya 50\% murid yang memiliki hasil belajar yang baik meningkat menjadi $65.6 \%$ dan siklus ke tiga menjadi $100 \%$ murid yang memiliki hasil belajar yang baik.

Data yang diperoleh menunjukkan bahwa setelah dilakukan penerapan alat edukatif simulasi komputer, maka terbukti adanya pengaruh yang ke arah yang positif dalam meningkatkan hasil belajar permainan bola besar murid pada mata pelajaran pendidikan jasmani dan olahraga, penekanan ini dilakukan dengan melakukan pendampingan kepada murid pada saat melakukan simulasi yaitu dengan satu murid satu pendamping.

Karena adanya pengaruh positif metode belajar simulasi dalam rangka meningkatkan hasil belajar permainan bola besar murid pada mata pelajaran pendidikan jasmani dan olahraga maka dalam penelitian ini penulis dapat memberikan beberapa harapan bahwa kepada guru dapat menerapkan alat edukatif simulasi komputer dalam rangka meningkatkan hasil belajar permainan bola besar murid pada mata pelajaran Pendidikan jasmani dan olahraga. Juga kepada murid untuk dapat selalu mengulang-ulang penggunaan alat edukatif simulasi komputer dan selalu melatih logika dan implementasi dari belajar permainan bola besar agar lebih terampil dan semakin memahami ilmu pendidikan jasmani dan olahraga yang dipelajari.

Hal ini juga ditegaskan oleh Rahman, dkk (2018) melalui upaya pengembangan yang dilakukan dalam pembelajaran akan membuat seorang tenaga pendidik akan terus maju dalam mencapai keberhasilan pembelajarannya.

\section{SIMPULAN}

Berdasarkan hasil penelitian yang telah diuraikan di atas, maka kesimpulan pada penelitian tindakan kelas dengan menerapkan kepada siswa di SMP Negeri 4 Siak Hulu dengan teknik analisis kualitatif diperolah hasil bahwa terbukti dengan penerapan metode simulasi mampu meningkatkan kemampuan penguasaan teknik dasar permainan bola besar.

\section{DAFTAR RUJUKAN}

Achsin, A. 1986. Media Pendidikan dalam Kegiatan Belajar Mengajar. Ujung pandang: IKIP Ujung Pandang Press

Arsyad, Azhar. 2002. Media Pembelajaran. Jakarta: PT. Raja Grafindo Persada 
Bruner, J. S. 1966. Toward a Theory of Instruction. Harvad University. Cambridge

Departemen Pendidikan Nasional Direktorat Jenderal Manajemen Pendidikan dasar dan Menengah, 2006, Pedoman Pembelajaran di taman kanak-kanak. Penerbit Depdikbud, Jakarta.

Moh. Uzer Usman. 2005. Menjadi Guru Profesional. Bandung : Remaja Rosdakarya.

Rahman, F., \& Suroto, B. (2018). Model Pengembangan Kinerja Dosen Swasta (Studi pada Karyawan yang berprofesi sebagai Dosen). Human Sustainability Procedia.

Surakhmad, Winarno. 1982. Pengantar Penelitian Ilmiah, Dasar, Metode, Teknik. Bandung: Transito

Suryosubroto. 2002. Proses Belajar Mengajar Di Sekolah. Jakarta: Rineka Cipta

Nasution, 1996, Metode Penelitian Naturalistik Kualitatif, Penerbit Tarsito, Bandung.

Patmonedowo, Soemiartri. 1995, Pendidikan Anak Prasekolah. Penerbit Rineka, Jakarta.

Purwanto, Ngalim, 1990, Psikologi Pendidikan. Penerbit Remaja Rosdakarya, Bandung. 